\section{PERLINDUNGAN \\ KONSUMEN \\ DI SEKTOR JASA \\ KEUANGAN \\ PERBANKAN}

Irma Sari Permata

${ }^{1}$ Fakultas Ekonomi dan Bisnis, Universitas Pancasila, Jakarta

Selatan, Indonesia

Artikel

Diterima : 13 Januari 2020

Disetujui : 17 Januari 2020

Email :

sari.permata11@univpancasila.ac.id

\begin{abstract}
Abstrak
Lembaga keuangan sektor perbankan merupakan salah satu Lembaga Keuangan yang dijadikan sebagai ukuran kemajuan dari suatu negara. Untuk mewujudkan sistim keuangan yang tumbuh secara berkelanjutan dan stabil, serta mampu melindungi kepentingan konsumen maupun masyarakat, maka pemerintah membentuk OJK (Otoritas Jasa keuangan). Penelitian ini menggunakan data sekunder yang berkaitan dengan tingkat efektifitas perlindungan konsumen disektor jasa keuangan perbankan. Teknik pengumpulan data melalui observasi, studi pustaka. Hasil dari penelitian ini adalah perkembangan pengaduan konsumen di sektor keuangan perbankan. Diharapkan dari penelitian ini adanya peningkatan edukasi dengan mengadakan sosialisasi pada konsumen serta melakukan pemantauan dan survey terhadap bank yang berada, agar meminimalisir kesalahan yang dilakukan oleh pihak perbankan.
\end{abstract}

Kata Kunci: Sektor Perbankan, Perlindungan Konsumen

\begin{abstract}
Financial institutions of the banking sector are one of the financial institutions that serve as the measure of progress of a country. To realize the financial system that grows continuously and stable, and able to protect the interests of consumers and society, the Government established the OJK (Financial Services Authority). This research uses secondary data relating to the level of effectiveness of consumer protection of financial services. Data collection techniques through observation, library studies. The result of this research is the development of consumer complaints in the banking financial sector. It is expected that the research has increased education by conducting socialization on consumers and monitoring and surveying of banks, in order to minimize the mistakes committed by the banking sector
\end{abstract}

Keywords: Banking sector, Consumer protection 


\section{PENDAHULUAN}

Globalisasi dalam sistim keuangan dan pesatnya kemajuan di bidang teknologi informasi serta inovasi finansial telah menciptakan sistim keuangan yang sangat kompleks, dinamis, dan saling terkait antar sub sektor keuangan baik dalam hal produk maupun kelembagaan. Kemajuan teknologi informasi yang begitu pesat serta adanya tantangan bisnis yang mendunia menimbulkan dampak yang cukup signifikan terhadap industri jasa keuangan di negara kita. Apalagi timbulnya krisis moneter di negara-negara maju seperti Amerika dan beberapa negara Eropa lainnya menjadikan pemerintah memandang perlu adanya suatu sistim keuangan yang stabil, kuat, dan kredibel terhadap Lembaga jasa keuangan yang ada saat ini, baik di sekor Perbankan maupun Lembaga keuangan nonbank.

Pasal 4 Undang-Undang Nomor 21 Tahun 2011 tentang Otoritas Jasa Keuangan (OJK) menyebutkan bahwa OJK dibentuk dengan tujuan agar keseluruhan kegiatan jasa keuangan di dalam sektor jasa keuangan terselenggara secara teratur, adil, transparan dan akuntabel, serta mampu mewujudkan sistem keuangan yang tumbuh secara berkelanjutan dan stabil, dan mampu melindungi kepentingan konsumen dan/atau masyarakat.

Untuk mencapai tujuan tersebut khususnya terkait perlindungan kepentingan konsumen dan/atau masyarakat, OJK telah melakukan berbagai upaya perlindungan konsumen dan/atau masyarakat, yaitu antara lain melalui regulasi dan kebijakan yang efektif dan terintegrasi, pemberdayaan konsumen dan/atau masyarakat melalui peningkatan literasi dan inklusi keuangan, penguatan mekanisme penanganan pengaduan dan penyelesaian sengketa dan penguatan infrastruktur perlindungan konsumen serta penerapan sistem dua pilar pengawasan secara terintegrasi yaitu prudential dan market conduct serta melakukan penegakan hukum yang efektif.

Beberapa hal yang menjadi perhatian Otoritas Jasa Keuangan diantaranya pengawasan sektor jasa keuangan yang terintegrasi (konglomerasi), praktik perlindungan konsumen yang sama di semua sektor jasa keuangan dan belum optimalnya perlindungan konsumen sektor jasa keuangan. Perlindungan Konsumen di sektor jasa keuangan bertujuan untuk menciptakan sistem perlindungan konsumen yang andal, meningkatkan pemberdayaan konsumen, dan menumbuhkan kesadaran Pelaku Usaha Jasa Keuangan mengenai pentingnya perlindungan konsumen sehingga mampu meningkatkan kepercayaan masyarakat pada sektor jasa keuangan.

Sehubungan dengan itu, upaya perlindungan konsumen dan/atau masyarakat diarahkan untuk mencapai dua tujuan utama. Pertama, meningkatkan kepercayaan diri dari investor dan konsumen dalam setiap aktivitas dan kegiatan usaha di sektor jasa keuangan (Market Confidence); dan Kedua, memberikan peluang dan kesempatan untuk perkembangan bagi Pelaku Usaha Jasa Keuangan secara adil, efisien dan transparan dan di sisi lain Konsumen memiliki pemahaman hak dan kewajiban dalam berhubungan dengan Pelaku Usaha Jasa Keuangan mengenai karakteristik, layanan dan produk (Level Playing Field). Dalam jangka panjang, industri keuangan akan mendapat manfaat yang positif untuk memacu peningkatan efisiensi sebagai respon dari tuntutan pelayanan yang lebih prima terhadap 
pelayanan jasa keuangan sehingga dapat tercipta kultur perlindungan konsumen dalam setiap aktivitas bisnis pelaku usaha jasa keuangan dan pasar yang disiplin (market dicipline).

Seiring dengan terus dilakukannya upaya-upaya perlindungan konsumen dan/atau masyarakat, Indonesia dihadapkan pada isu dan tantangan perlindungan konsumen di sektor jasa keuangan yang begitu kompleks dan dinamis. Isu dan tantangan tersebut diantaranya adalah kurang berimbangnya persebaran pangsa pasar sektor jasa keuangan, ketidaksesuaian produk dan layanan sektor jasa keuangan terhadap kebutuhan masyarakat, belum terbentuknya budaya perlindungan konsumen di Indonesia, sinergi/kerjasama antar otoritas dalam sektor jasa keuangan, lemahnya penegakan hukum, belum optimalnya infrastruktur perlindungan konsumen sektor jasa keuangan, dan tantangan atas perkembangan sektor jasa keuangan secara global.

Tujuan Penelitian adalah; 1) Untuk mengetahui mengetahui fungsi Otoritas Jasa Keuangan secara umum; 2) Untuk mengetahui Mekanisme Pelaksanaan Fungsi Perlindungan Konsumen di Sektor Perbankan oleh Otoritas Jasa Keuangan. Manfaat Penelitian adalah; 1) Bagi Peneliti, merupakan media untuk memecahkan masalah secara ilmiah dan memberikan sumbangan pemikiran berdasarkan disiplin ilmu; 2) Bagi Akademisi, dapat menambah referensi, informasi dan wawasan untuk penelitian lebih lanjut atau sebagai bahan kepustakaan serta sumber pengetahuan; 3) Bagi Perusahaan, dapat digunakan sebagai bahan informasi dan masukan bagi pimpinan perusahaan atau bank dalam langka pengambilan langkah langkah kebijakan untuk mempertahankan dan meningkatkan tingkat probabilitas pada masa sekarang dan masa yang akan datang. Berdasarkan hal ini, maka penelitian merumuskan beberapa masalah sebagai berikut; 1) Bagaimana fungsi Otoritas Jasa Keuangan secara umum; 2) Bagaimana Mekanisme Pelayanan Pelaksaanan Perlindungan Konsumen di Sektor Perbankan oleh Otoritas Jasa Keuangan.

\section{KAJIAN TEORI}

\section{Otoritas Jasa Keuangan (OJK)}

Otoritas Jasa Keuangan, yang selanjutnya disingkat OJK, adalah lembaga yang independen dan bebas dari campur tangan pihak lain, yang mempunyai fungsi, tugas, dan wewenang pengaturan, pengawasan, pemeriksaan, dan penyidikan sebagaimana dimaksud dalam UndangUndang No. 21 Tahun 2011 Tentang Otoritas Jasa Keuangan. Otoritas Jasa Keuangan (OJK) adalah lembaga Negara yang dibentuk berdasarkan Undang-Undang Nomor 21 Tahun 2011 yang berfungsi menyelenggarakan sistem pengaturan dan pengawasan yang terintegrasi terhadap keseluruhan kegiatan di dalam sektor jasa keuangan baik di sektor perbankan, pasar modal, dan sektor jasa keuangan non-bank seperti Asuransi, Dana Pensiun, Lembaga Pembiayaan, dan Lembaga Jasa Keuangan lainnya.

Pasal 4 Undang-Undang Nomor 21 Tahun 2011 tentang Otoritas Jasa Keuangan menyebutkan bahwa Otoritas Jasa Keuangan dibentuk dengan tujuan agar keseluruhan kegiatan di dalam sektor jasa keuangan terselenggara secara teratur, adil, transparan, akuntabel dan mampu mewujudkan sistem keuangan yang tumbuh secara berkelanjutan dan stabil, serta mampu melindungi kepentingan 
konsumen maupun masyarakat. Dengan pembentukan Otoritas Jasa Keuangan, maka lembaga ini diharapkan dapat

mendukung kepentingan sektor jasa keuangan secara menyeluruh sehingga meningkatkan daya saing perekonomian. Selain itu, Otoritas Jasa Keuangan harus mampu menjaga kepentingan nasional. Antara lain meliputi sumber daya manusia, pengelolaan, pengendalian, dan kepemilikan di sektor jasa keuangan dengan tetap mempertimbangkan aspek positif globalisasi. Otoritas Jasa Keuangan dibentuk dan dilandasi dengan prinsip-prinsip tata kelola yang baik, yang meliputi independensi, akuntabilitas, pertanggungjawaban, transparansi, dan kewajaran (fairness).

\section{Konsep Edukasi dan Perlindungan Konsumen}

Fungsi edukasi dan perlindungan konsumen merupakan pilar penting dalam sektor jasa keuangan. Dalam pelaksanaannya, konsep Edukasi dan Perlindungan Konsumen sektor jasa keuangan di Otoritas Jasa Keuangan dikelompokkan menjadi dua, yaitu: 1. Bersifat Preventif (Preventive Actions). Preventive actions dilakukan dalam bentuk pengaturan dan pelaksanaan di bidang edukasi dan perlindungan konsumen. Edukasi dilakukan melalui berbagai media dan cara. 2. Bersifat Represif (Represive Actions). Represive Actions dilakukan dalam bentuk penyelesaian pengaduan, fasilitasi penyelesaian penyelesaian sengeketa, penghentian kegiatan atau tindakan lain, dan pembelaan hokum untuk melindungi konsumen.

\section{Perlindungan Konsumen}

Pengertian Konsumen Konsumen adalah pihak-pihak yang menempatkan dananya dan/atau memanfaatkan pelayanan yang tersedia di Lembaga Jasa Keuangan antara lain nasabah pada Perbankan, pemodal di Pasar Modal, pemegang polis pada perasuransian, dan peserta pada Dana Pensiun, berdasarkan peraturan perundang-undangan di sektor jasa keuangan. Pengertian Perlindungan Konsumen Perlindungan Konsumen adalah perlindungan terhadap Konsumen dengan cakupan perilaku Pelaku Usaha Jasa Keuangan. Perlindungan Konsumen menerapkan prinsip: 1. Transparansi 2. Perlakuan yang adil 3. Keandalan 4. Kerahasiaan dan keamanan data/informasi Konsumen 5. Penanganan pengaduan serta penyelesaian sengketa Konsumen secara sederhana, cepat, dan biaya terjangkau.

\section{METODE}

Penelitian ini menggunakan metode langsung dan tidak langsung. Metode secara langsung dengan mengikuti pelaksanaan sosialisasi perlindungan konsumen sektor jasa keuangan yang diadakan oleh Fakultas Ekonomi dan Bisnis Universitas Pancasila dengan menghadirkan narasumber internal dari OJK yaitu bapak Sarwin Kiko Napitupulu, beliau sebagai Kepala Bagian Pelayanan Konsumen Terintegrasi 1 dan Rija Fathul Bari dengan fasilitatornya Suci Aprilusi. Waktu kegiatan pada hari Jumat, tanggal 15 November 2019 dan tempat kegiatannya di Aula lantai IV FEB-Universitas Pancasila. Pelaksanaan sosialisasi ini dilakukan dalam bentuk pemaparan materi secara lebih santai (nonformal) oleh narasumber kepada peserta dan memberikan kesempatan lebih banyak untuk 
berdiskusi dengan para peserta. Untuk memberikan Batasan, cakupan dan fokus diskusi, maka narasumber mempresentasikan materi sesuai dengan pedoman dalam penyajian materi sosialisasi ini. Sedangkan metode tidak langsung dengan mengumpulkan data sekunder dari studi pustaka.

\section{HASIL \& PEMBAHASAN}

Kegiatan PkM ini dilaksanakan melalui tahapan-tahapan sebagai berikut; 1. Rapat perencanaan kegiatan yang dihadiri oleh seluruh anggota tim pengabdian, 2. Melakukan kontak awal untuk bekerja sama dengan OJK dalam hal memberikan sosialisasi mengenai kebijakan perlindungan konsumen di sektor jasa keuangan dan pengelola keuangan ditujukan kepada para mahasiswa dan dosen FEB Universitas Pancasila yang hadir sekitar 150 peserta. Hal ini dilakukan sebagai upaya untuk meningkatkan pemahaman para mahasiswa/i mengenai kebijakan perlindungan konsumen di sektor keuangan dan pengelolaan keuangan bijak bagi generasi millennial, 3. Narasumber memaparkan materi sosialisasi dengan menarik dan tidak bosan karena diselingi dengan pelaksanaan kuis secara digital. Adapun pemaparan materi mengenai penjelasan fungsi otoritas jasa keuangan secara umum dan penjabaran mengenai mekanisme pelayanan pelaksanaan perlindungan konsumen di sektor keuangan.

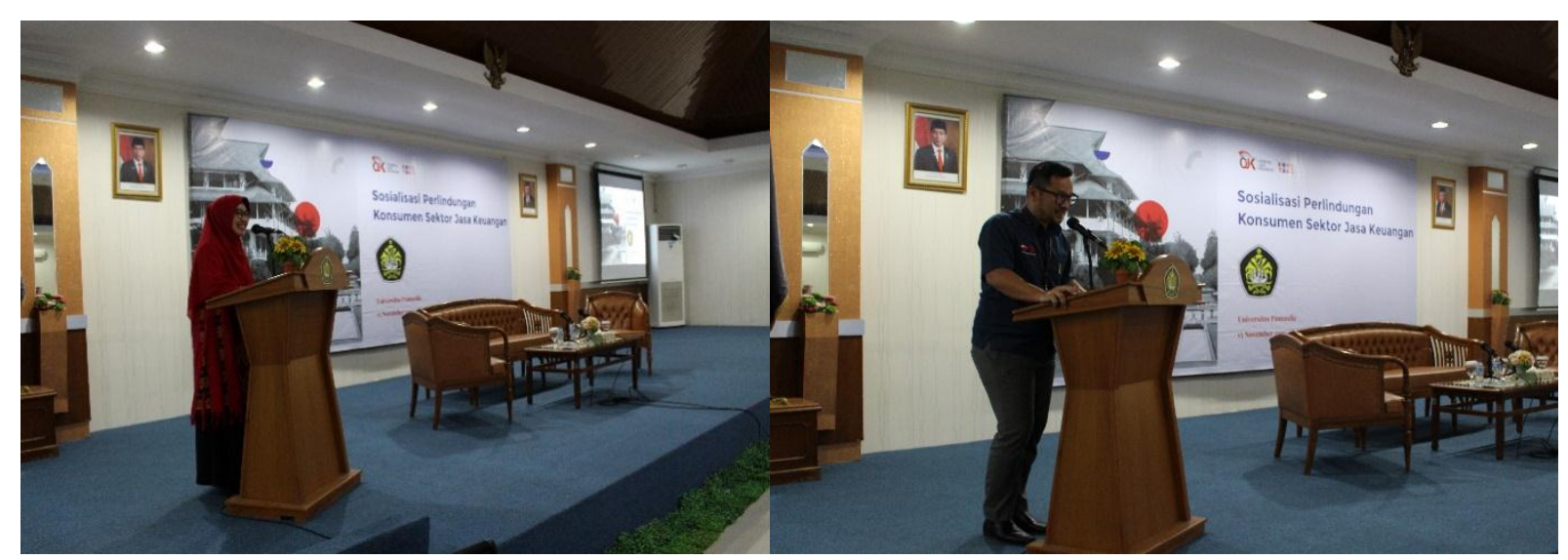

Gambar 1. Pemaparan oleh Dekan dan Narasumber
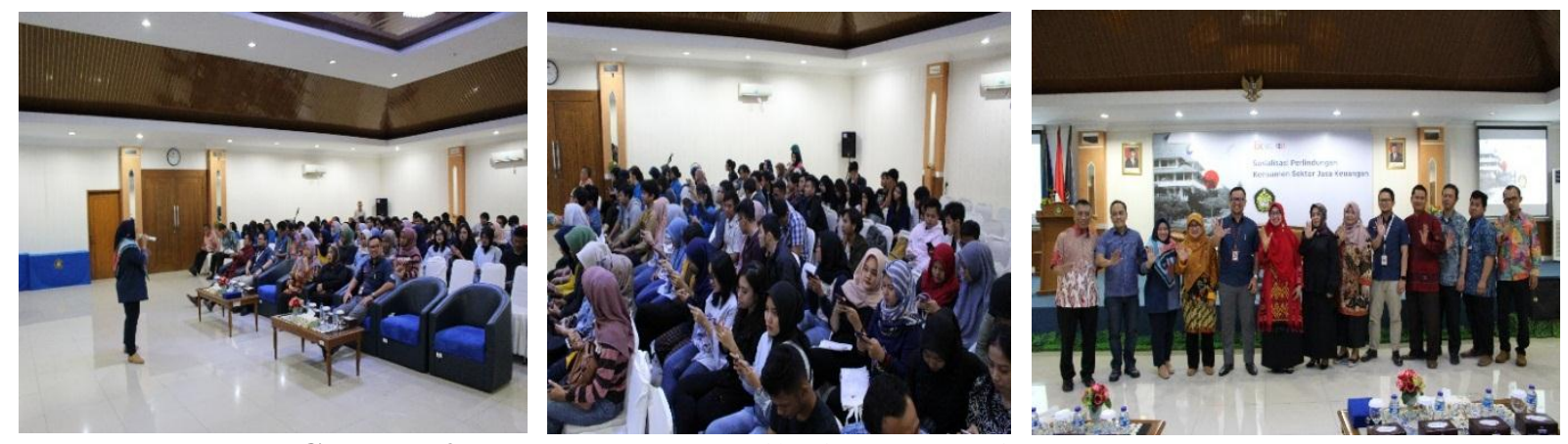

Gambar 2. Peserta yang Mengikuti acara Otoritas Jasa Keuangan 


\section{Fungsi Otoritas Jasa Keuangan secara umum}

Fungsi OJK secara umum adalah mengadakan sistim pengaturan serta monitoring untuk semua aktivitas di sector jasa keuangan secara terintegrasi. OJK merupakan pusat dari seluruh aktivitas pada sektor keuangan di tanah air. Untuk merealisasikan fungsi tersebut, OJK memilih nilai-nilai strategis yang merupakan landasan bagi Lembaga pengawas keuangan independent tersebut, yaitu; Integritas dan Profesionalisme.

\section{Integritas}

OJK harus mampu menjalankan fungsinya dengan konsisten, adil, dan obyektif sebagaimana kode etik yang harus dijunjung tinggi sesuai kebijakan yang diberlakukan dalam organisasi yaitu komitmen yang tinggi akan kejujuran dan konsistensi. Karena akan memberi pengaruh bagi kepentingan orang banyak tentunya semua orang yang terlibat menjalankan kewenangan OJK harus mempunyai integritas yang tinggi.

\section{Profesionalisme}

Hasil kerja terbaik dibarengi dengan sikap bertanggungjawab. Yang dapat menjadi bagian dari Lembaga independent ini hanyalah orang-orang terbaik mengingat OJK merupakan tampuk dari semua aktivitas pada industri jasa keuangan di Indonesia.

Untuk dapat mencapai tujuan tentunya fungsi OJK harus terealisasi sesuai dengan nilai-nilai meliputi nilai sinergi merupakan upaya untuk menyelenggarakan kolaborasi yang baik dengan semua pemangku kepentingan secara produkif dan bermutu dengan mereka yang berada dalam lingkungan internal serta eksternal; nilai inklusif merupakan kesediaan untuk terbuka serta menerima keanekaragaman pemengku kepentingan juga mengembangkan akses seta peluang untuk masyarakat luas terhadap industri keuangan; dan nilai visioner artinya OJK mempunyai wawasan yang luas serta dapat memproyeksikan keadaan di masa depan serta mampu memberikan jalan keluar hasil dari buah pikir walaupun di luar kebiasaan dan rutinitas.

Secara detail tugas-tugas OJK adalah; 1) Merancang peraturan serta melakukan monitoring terhadap aktivitas industry jasa keuangan pada bidang perbankan; 2) Merancang peraturan serta melakukan monitoring terhadap aktivitas industry jasa keuangan pada bidang pasar modal; 3) Merancang peraturan serta melakukan monitoring terhadap aktivitas industry jasa keuangan pada bidang lainnya, misalnya asuransi, dana pension, serta Lembaga keuangan lainnya.

\section{Mekanisme Pelayanan Pelaksaanan Perlindungan Konsumen di Sektor Perbankan oleh Otoritas Jasa Keuangan}

Mekanisme Pelayanan dan Penyelesaian Pengaduan Konsumen Pengaduan adalah ungkapan ketidakpuasan Konsumen yang disebabkan oleh adanya kerugian dan/atau potensi kerugian finansial pada Konsumen yang diduga karena kesalahan atau kelalaian Lembaga Jasa Keuangan. Adapun tata cara penyampaian dan penyelesaian pengaduan konsumen pada sektor Perbankan adalah seperti gambar berikut: 


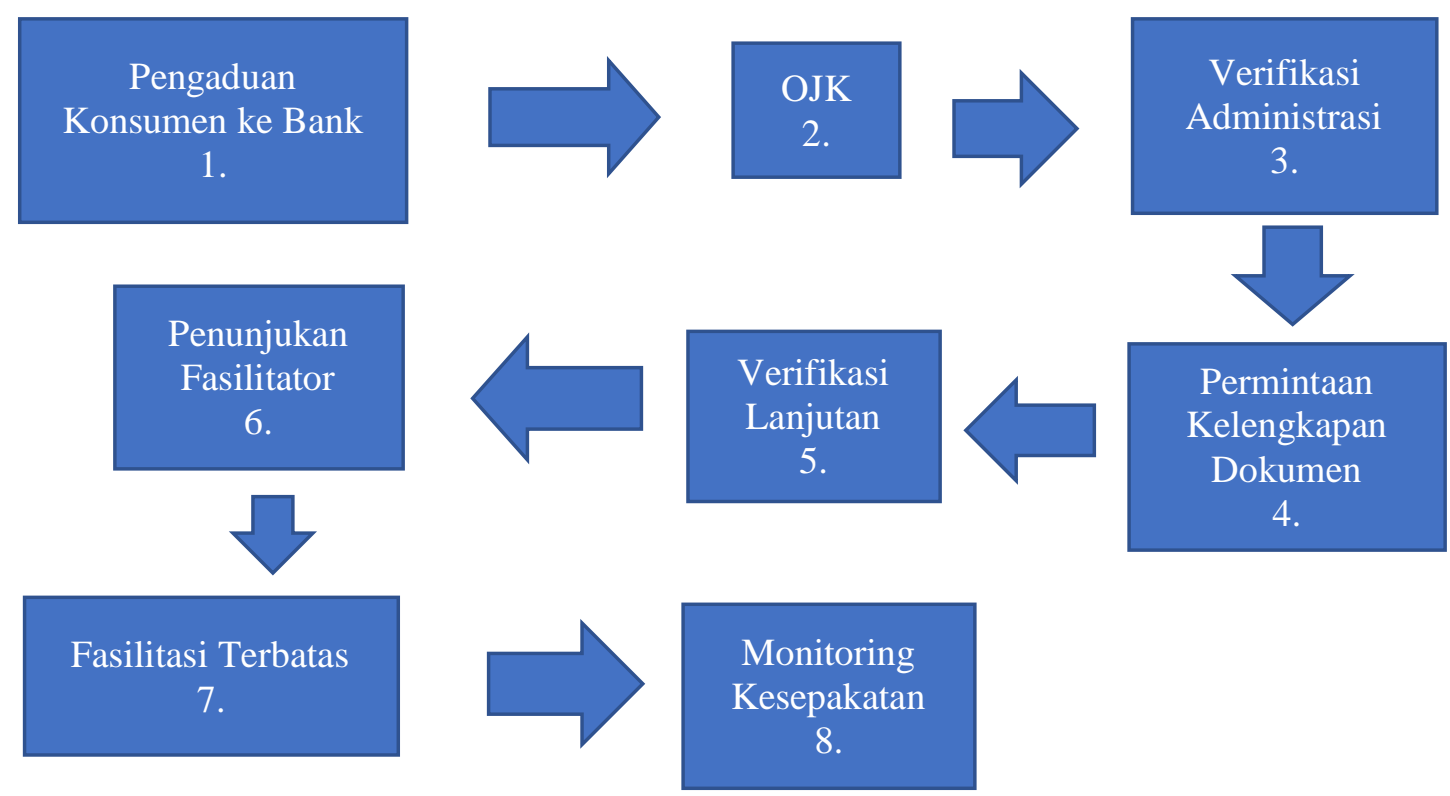

Gambar 3. Tata Cara Penyampaian dan Penyelesaian Pengaduan Konsumen pada Sektor Perbankan. Sumber: https://konsumen.ojk.go.id

1. Pengaduan. Tahap pertama ini dapat dilakukan konsumen dengan memperhatikan beberapa hal sebagai berikut: a. Konsumen telah menyampaikan pengaduan kepada Penyelenggara atau Bank dan Lembaga Jasa Keuangan Lainnya dan telah ditindaklanjuti sesuai Ketentuan, namun tidak terdapat kesepakatan antara Konsumen dengan Penyelenggara. b. Permasalahan yang diadukan merupakan masalah perdata yang belum pernah diputus oleh Bank dan Lembaga Jasa Keuangan atau peradilan atau belum terdapat kesepakatan yang difasilitasi oleh lembaga mediasi atau lembaga alternatif penyelesaian sengketa lainnya. c. Terdapat potensi kerugian finansial yang ditimbulkan oleh Penyelenggara atau Bank dan Lembaga Jasa Keuangan yang bersangkutan dengan nominal paling banyak Rp 500.000.00,00 (Lima Ratus Juta Rupiah). 2. Pengaduan diajukan ke Otoritas Jasa Keuangan. Jika Konsumen belum sepakat dengan pihak Bank atau Lembaga Jasa Keuangan maka konsumen bisa menyampaikan pengaduan ke Otoritas Jasa Keuangan (OJK). Dengan berbagai bentuk dan macam Layanan Konsumen Otoritas Jasa Keuangan (OJK), konsumen dengan mudah dapat menyampaikan pengaduan melalui cara berikut ini: a. Surat Tertulis. b. Website. c. EMAIL. d. PELAKU (Pusat Edukasi, Layanan Konsumen, dan Akses Keuangan UMKM) yang terdapat pada Kantor Regional maupun Kantor OJK. e. Telepon. f. FAX. 3. Verifikasi Administrasi. 4. Permintaan Kelengkapan Dokumen. 5. Verifikasi Lanjutan 6. Penunjukan Fasilitator 7. Fasilitasi Terbatas 8. Monitoring Kesepakatan.

\section{SIMPULAN}

Dari hasil kegiatan sosialisasi ini maka dapat disimpulkan bahwa pentingnya pengetahuan tentang perlindungan konsumen di sektor jasa keuangan sehingga perguruan tinggi mempunyai peran yang sangat strategis dalam melaksanakan sosialisasi kepada masyarakat luas sebagai sarana pembelajaran efektif tentang perlindungan konsumen sebagai wujud tridharma perguruan tinggi. 
Disarankan agar kegiatan ini dapat dilaksanakan secara berkala dan mengumpulkan masalahmasalah terkini yang sedang dihadapi masyarakat untuk dibahas, sehingga masyarakat luas mendapatkan pemahaman mengenai perlindungan konsumen dengan lebih efektif.

\section{DAFTAR PUSTAKA}

Dwi Rahmadhani, Anisa. 2017. Efektivitas Perlindungan Konsumen Terhadap Sektor Perbankan Oleh Otoritas Jasa Keuangan (OJK) (Studi Kasus Karisidenan Surakarta). Universitas Sebelas Maret Surakarta.

D. Hadad, Muliaman. 2016. Salinan Peraturan Otoritas Jasa Keuangan Nomor 76/POJK.07/2016. Tentang Peningkatan Literasi dan Inklusi Keuangan di Sektor Jasa Keuangan Bagi Konsumen dan/atau Masyarakat. Jakarta.

Kasmir. 2013. Bank dan Lembaga Keuangan Lainnya. Edisi Revisi. Rajawali Pers. Jakarta. Riana H, Duma. Direktur Manajemen Srategis, EPK dan Kemitraan Pemerintah Daerah. 2018. Materi Pengenalan Otoritas Jasa Keuangan (OJK) Universitas 17 Agustus 1945. Jakarta.

S. Soetiono, Kusumaningtuti. 2015. Modul Workshop Perlindungan Konsumen di Sektor Jasa Keuangan Bidang Edukasi dan Perlindungan Konsumen. Tim Penyusun.

S. Soetiono, Kusumaningtuti. 2013. Pointers Sambutan Seminar Setengah Hari. "Moment of Truth : Manajemen Pengaduan Sektor Jasa Keuangan Indonesia”. Jakarta.

S. Soetiono, Kusumaningtuti. 2017. Salinan Surat Edaran Otoritas Jasa Keuangan Nomor 30/SEOJK.07/2017. Tentang Pelaksanaan Kegiatan Dalam Rangka Meningkatkan Literasi Keuangan di Sektor Jasa Keuangan. Jakarta.

S. Soetiono, Kusumaningtuti. 2014. Surat Edaran Otoritas Jasa Keuangan Nomor 2/SEOJK.07/2014. Tentang Pelayanan dan Penyelesaian Pengaduan Konsumen pada Pelaku Usaha Jasa Keuangan. Jakarta.

Undang-Undang Republik Indonesia Nomor 21 Tahun 2011. Tentang Otoritas Jasa Keuangan.

Peraturan Otoritas Jasa Keuangan Nomor 1/POJK.07/2013 Tentang Perlindungan Konsumen Sektor Jasa Keuangan. Jakarta. Penjelasan Atas Peraturan Otoritas Jasa Keuangan Nomor 1/POJK.07/2013. Tentang Perlindungan. Konsumen Sektor Jasa Keuangan. Jakarta

www.ojk.go.id Diakses pada tanggal 13 Januari 2020, pukul 12.30 WIB.

www.analisaforex.com/otoritas-jasa-keuangan-ojk. Diakses pada 13 Januari 2020, pukul 12.05 